\title{
(Un)Patriotic Nuances? Evaluating the Nature of the 'Reporter Voice' in Hard News Reports on the Renewal of 'Sanctions' in Zimbabwe
}

\author{
Collen Sabao (Corresponding author) \\ Department of African Languages, Stellenbosch University \\ Private Bag X1, Matieland 7602, South Africa \\ Tel: 27-604-438-151Ｅ-mail:sabaocol@gmail.com

\begin{abstract}
Marianna Visser
Department of African Languages, Stellenbosch University

Private Bag X1, Matieland 7602, South Africa
\end{abstract} \\ E-mail:mwv@sun.ac.za
}

Received: April 24, 2013 Accepted: May 28, $2013 \quad$ Published: June 28, 2013

doi:10.5296/ijl.v5i3.3934 URL: http://dx.doi.org/10.5296/ijl.v5i3.3934

\begin{abstract}
On the eve of the heavily contested 2002 harmonised Zimbabwean Presidential and Parliamentary elections, the United States of America (USA) and the European Union (EU) imposed 'sanctions' on Zimbabwe. In the course of time, subsequent annual renewals of the 'sanctions' were effected by the same imposers. This article analyses the discourse linguistic notion of 'objectivity' in 'hard' news reports on the renewal of these USA and EU imposed 'sanctions' in Zimbabwean newspapers. The article compare the textuality of 'hard' news reports from two English language Zimbabwean daily newspapers, The Herald ${ }^{1}$ and NewsDay ${ }^{2}$, by analysing how language and linguistic resources are used evaluatively in manners that betray authorial attitudes and ideological stance. Specifically, the analyses focus on the way(s) in which the news reports uphold or flout the 'objectivity' ideal as explicated
\end{abstract}

\footnotetext{
${ }^{1}$ One of Zimbabwe's daily newspapers owned and controlled by the government.

${ }^{2}$ One of Zimbabwe's privately owned daily newspapers.
} 


\section{Macrothink}

International Journal of Linguistics

ISSN 1948-5425

through the 'reporter voice" ${ }^{3}$ configuration of Appraisal Theory and Systemic Functional Linguistics (SFL). This is done through the analysis of how the linguistic choices made by the reporter(s) at lexical, lexicogrammatical, syntactic and syntagmatic levels betray conscious subjective evaluative uses of language and in the process further some assumed ideological position/stance.

Keywords: Bias, Hard news, Objectivity, Reporter Voice, Sanctions, Zimbabwe

\footnotetext{
3 The notion of 'reporter voice' is a linguistic configuration used to identify rhetorical markers by which a journalist implicitly or explicitly selects languages in order to win an audience towards his/her point of view.
} 


\section{Introduction and Background to the Zimbabwe 'Sanctions' Debate}

Following the heavily contested and violence marred harmonised Presidential and Parliamentary elections of 2002 in Zimbabwe, the United States of America (USA) and the European Union (EU) at large imposed 'sanctions' (which in essence were restrictions, travel and trade) on named individuals ${ }^{4}$ within the ranks of governance in the country. Affected individuals were largely drawn from the Robert Gabriel Mugabe led Zimbabwe African National Union Patriotic Front (ZANU PF) political party. The 'sanctions' were also extended to named entities they control. Those affected by the sanctions are broadly speaking, the President of the Republic, Robert Gabriel Mugabe, his immediate family and close relatives as well as his political allies. This group largely constituted of his cabinet/ministers, heads of security agencies, that is, the Central Intelligence Organisation (CIO), the Zimbabwe Republic Police, the Zimbabwe National Army and the Zimbabwe Prisons Services as well as their immediate families. The 'illegal sanctions', which are largely framed as travel and trade restriction on the named individuals forbade United States nationals to 'do business with [these named persons], these designated entities or with other entities they control'. This translates thus to the sanctions also affecting named corporations and organisations run by the embargoed individuals.

Despite the ZANU PF government referring to them as 'sanctions' the USA and EU have continuously insisted that they are mere restrictions whose existence is justified by ZANU PF's gross violations of human rights and electoral laws. The USA argues that the 'sanctions' were imposed on specified Zimbabwean nationals and not the country as a result of an observed high prevalence of gross human rights violations by the Zimbabwean ruling elite (specifically the ZANU PF leadership). They 'sanctions', the USA and EU argue, were meant to 'force' the Zimbabwean ruling elite to implement reform(s) towards democratisation. They intimate that, in response to human rights and election-related abuses perpetrated between 2001 and 2008, they (the U.S. and EU) adopted a variety of measures designed to promote reform. Some of these measures are targeted at specific individuals (for example, asset freezes and travel bans) ${ }^{6}$.

"The sanctions on Zimbabwe were introduced in response to political violence, human rights abuses and rule of law violations, as well as deteriorating democratic standards that followed the violent election processes in 2000 and 2002. In many respects these core problems remain. Political parties and civil society groups alike continue to refer to ongoing concerns about political violence, repression and reform deficits. The sanctions are neither comprehensive nor illegal, as often suggested by ZANU-PF. They include a set of "restrictive measures" introduced and modified over the last decade by the U.S., EU and other countries targeting specific individuals and entities. In addition, an arms embargo by these countries prevents the sale of weapons and other items that could be

\footnotetext{
4 See: http://www.treasury.gov/resource-center/sanctions/Programs/Pages/zimb.aspx for the full list of embargoed individuals and companies/corporation.

5 The term 'illegal sanctions' is framed in scare quotes here because it is the way in which ZANU PF has officially described the sanctions as. This was on the basis that they, as a political party and government, strongly believe the sanctions are not warranted and justified. This position has been made official on both the ZANU PF website (http://www.zanupf.org.zw) as well as in many speeches made by, and interviews with the President Robert Mugabe.

6 'Zimbabwe's Sanctions Standoff', Crisis Group Africa Briefing N86, 6 February 2012.
} 
used for internal repression"7.

The ZANU PF government's response to these charges by the USA and EU has been one of hostility and aggression - one that challenges the legitimacy of the sanctions as well as the sincerity and intent of especially Britain ${ }^{8}$ to the cause of democracy and good governance in Zimbabwe. The President of the Republic and the First Secretary of ZANU PF, Robert Gabriel Mugabe, has made this position clear at several foras, both in his capacity as ZANU PF leader as well as Zimbabwe's President. For example, responding to threats of possible indictment at the International Criminal Court for these alleged human rights violations that are allegedly the reason for the sanctions on Cable News Network's (CNN's) Amanpour ${ }^{9}$ on the eve of his address to the United Nations General Assembly to appeal for the repulsion of the 'sanctions', Mugabe made the following remarks which question the sincerity and intent of Britain in imposing sanctions against Zimbabwe,

I am not concerned about the International Criminal Court. I am concerned about Zimbabwe and I am concerned about the lives of the people of Zimbabwe. And don't forget it was my party that brought democracy to the country and not the British. We had to fight the British for democracy... ${ }^{10}$

An important dimension to note, with regards to the 'sanctions' issue is that, despite calls for the removal of the sanctions both ZANU PF (in particular through the ZANU PF spearheaded Anti-Sanctions and Petition Campaign of 2011) as well as from the Southern African Development Community (SADC), soon after the 2008 Presidential Elections in Zimbabwe, regarded as the most violent in the history of the country and in which there were observed irregularities in the administration of the election - notably, the refusal by the ZANU PF government to accredit independent observers (especially from the European Union), as well as the unprecedented and yet unexplained delay in announcing election results ${ }^{11}$ and the subsequent one man run-off pitting Mugabe alone after the all the opposition parties

\footnotetext{
${ }^{7}$ Ibid

${ }^{8}$ Britain is historically the country's former colonial masters.

${ }^{9}$ Christiane Amanpour interviews Robert Mugabe on CNN Amanpour - 24 September, 2009.
}

http://edition.cnn.com/2009/WORLD/africa/09/25/zimbabwe.mugabe.amanpour.transcript/index.html

10 "Christiane Amanpour interviews Robert Mugabe" on CNN Amanpour - 24 September, 2009. http://edition.cnn.com/2009/WORLD/africa/09/25/zimbabwe.mugabe.amanpour.transcript/index.html

11 The election was held on the 29 March 2008. The results were only announced by the chief electoral officer on 2 May 2008 . 
(especially the Morgan Tsvangirai led MDC-T) withdrew citing violence and intimidation ${ }^{12}$ on its supporters as well as allegations of election theft by ZANU PF - the US and EU made a further extension/reaffirmation of the 'sanctions'.

This position, the extension of the sanctions was further reaffirmed again by the USA in March 2011 and March 2012 on grounds that ZANU PF was still demonstrating political intolerance and was obstinate to fully implement the provisions of the Global Political Agreement (GPA). The GPA is a political agreement forming a Government of National Unity (GNU) - a power-sharing government between Zimbabwe's three major political parties - the Zimbabwe African National Union Patriotic Front (ZANU PF) - led by the incumbent president Robert Gabriel Mugabe and the two formation Movement for Democratic Change (MDC) that is, $\mathrm{MDC}^{-\mathrm{T}^{13}}$ (the formation led by Morgan Tsvangirai, regarded as the biggest political challenge to Mugabe since the attainment of independence in 1980) and MDC-N (the breakaway formation once led by Professor Arthur Mutambara and now led by Professor Welshman Ncube). The political settlement was a culmination of negotiations after the heavily disputed 2008 presidential elections.

\section{The Structure and Textuality of 'Hard' News Reports}

The 'hard' news report is one that is typically characterised by facticity, reporting nothing but the facts. It must be seen to steer away from the expression of authorial subjectivities. Of course, while such news and editorials draw resources and contexts from similar experiential scenes, the difference between the news report and the editorial is evident in the choice of linguistic resources used to achieve their different communicative purposes (McCabe and Heilman, 2007). 'A ['hard' news] report purportedly has the mission of presenting events that took place out there in the world in as objective a way possible, while an editorialist had the express purpose of providing commentary, or evaluating those events.' Typically, editorials are thus characterised by an overt presence of interpersonal devices, whereas news reports on the other hand, whilst not entirely disguising authorial presence and evaluations, attempt to do so and are not typically characterised by a high proliferation of overt interpersonal authorial subjectivities and subjective authorial evaluative expressions, that is, linguistic resources.

\footnotetext{
12 The Zimbabwe Electoral Commission (ZEC) announced on 2 May 2008 that Tsvangirai won 47.9\% and Mugabe won $43.2 \%$, thereby necessitating a run-off which was to be held on 27 June 2008. Despite Tsvangirai's continued claims to have won a first round majority, he decided to participate in the second round. The period following the first round was marked by political violence. ZANU-PF and the MDC each blamed the other's supporters for perpetrating the violence; Western governments and prominent Western organisations blamed ZANU-PF for the violence. On 22 June 2008, Tsvangirai announced that he was withdrawing from the run-off, describing it as a "violent sham" and saying that his supporters risked being killed if they voted for him. The second round of elections went ahead with Mugabe as the only actively participating candidate, although Tsvangirai's name remained on the ballot. Mugabe won the second round by an overwhelming margin and was sworn in for another term as President on 29 June.

${ }^{13}$ The two factions of MDC are identified by the first letters of the surnames of their leaders. MDC-T is thus the faction led by Morgan Tsvangirai and MDC-N is the faction led by Professor Welshman Ncube. MDC-N was formerly known as MDC-M when it was still being led by Professor Arthur Mutambara.
} 


\section{Macrothink}

'Hard' news reports must typically report news in as dispassionate a manner as possible. They must be strictly 'objective' texts which are constructed 'in such a way that there are no explicit linguistic evidence of the authors' value judgments'. McCabe and Heilman (2007), explain this by arguing that, when an author writes an event/'hard' news report, s/he will not tend to linguistically encode any value judgments. 'Hard' news articles must thus attempt to project an aura of 'objectivity' in comparison to editorials/commentaries whose concerns are to air opinions, but this is not always the case as they often are loaded with attitudinal meanings - occurring as both inscribed and/or invoked authorial evaluations as well as attributed inscribed and/or invoked evaluations. The structure of the 'hard' news report is expressed from journalistic and linguistic perspectives through the Inverted Pyramid Structure and the Orbital Structure respectively. The configurations are schematised in Figure 1 and Figure 2 below:

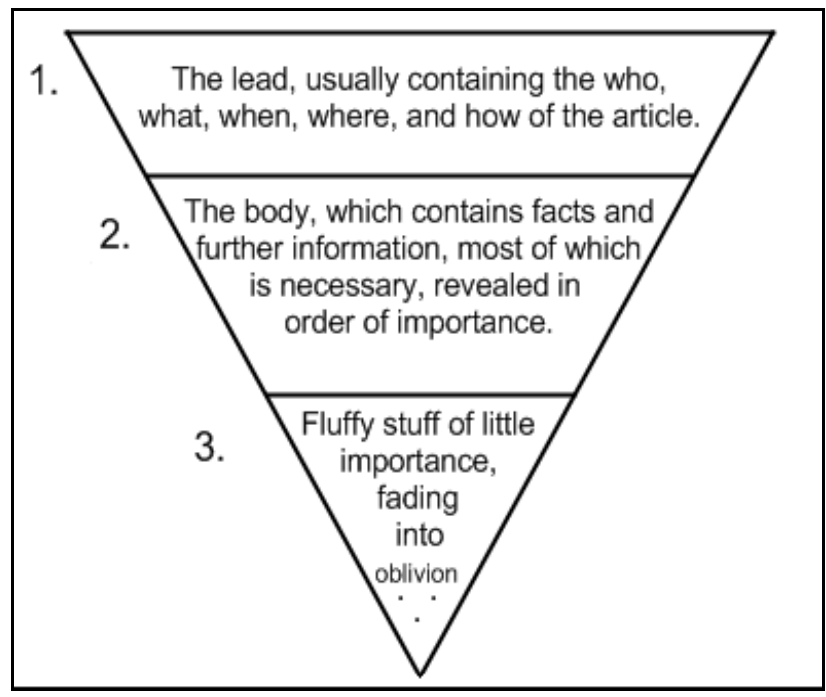

Figure 1. The Inverted Pyramid Structure

According to Thomson, et al (2008) the 'inverted pyramid' structure is a configuration by which the 'most important information' in the news/news report comes first. Progressively after that, the report develops gradually through to what is 'least important'. Thomson, et al (2008) argue in this regard that,

It is frequently held that authorial neutrality and the inverted pyramid structure are key factors in the distinction and uniqueness and distinctiveness of the modern hard news report as a text type. (Thomson, White and Kitley, 2008: 1)

White and Thomson (2008) in relation to this make an imperative reflection that the assessment of what constitutes as the 'most important' and the 'least important' aspects of the news/news report are 'both culturally and ideologically relative'. In other words, they are subject to authorial evaluations and judgment. 


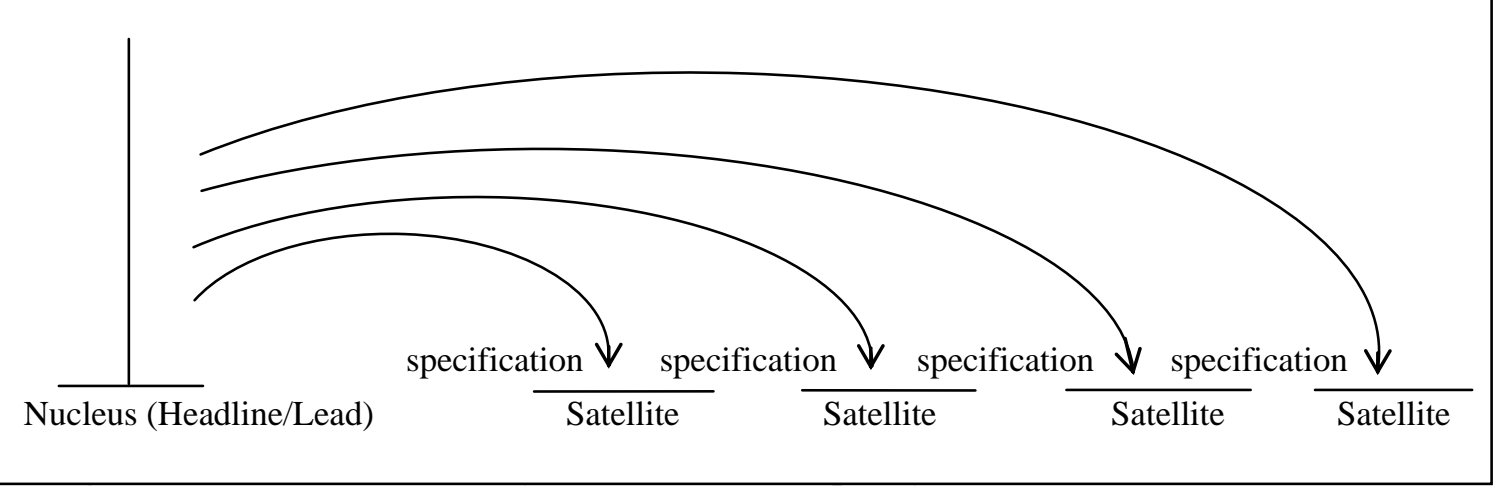

Figure 2. Orbital Structure of 'hard news' (Adapted from White and Thomson, 2008)

The textual organisation of 'hard news' as represented in the orbital structure, as White and Thomson (2008) explicate, means that a news report can be divided into two sections, the headline/lead and the body. The headline/lead forms 'the nucleus': the summary of the concerns of the news report summated in both the headline and the opening sentence/paragraph of the news report. The body, White and Thomson (2008), like Thomson et al (2008) argue is not chronologically organised but is constituted of different sections which act as 'satellites'. These satellites serve to elaborate on the 'claims' made by the headline/lead in a variety of establishable ways. They, after Iedema et al (1994) and White (2000a) refer to this textual organisation of the 'hard news' report as "orbital". The satellites according to Iedema et al (1994) perform, in the news report, one of the five broad functions of:

- Elaboration or Reiteration: One sentence or a group of sentences provides more detailed description or exemplification of information presented in the headline/lead, or acts to restate it or describe the material in the headline/lead in different terms.

- Causes: One or more sentences describe the causes or reason for some aspect of the "crisis point" presented in the headline/lead

- Consequences: One or more sentences describe the consequences flowing from some element of the crisis point of the headline/lead.

- Contextualisation: One or more sentences places some aspect of the crisis point of the headline/lead in a temporal, spatial or social context. For example, the geographical setting will be described in some detail or the "crisis point" will be located in the context of preceding, simultaneous or subsequent events. Prior events of a similar nature may be described for the purpose of comparison and.

- Attitudinal assessment/Appraisal: Some form of judgement or evaluation is passed on some element of the headline/lead.

\section{Theory: Appraisal, the 'Reporter Voice' and Evaluative Use of Language}

Appraisal Theory is a framework that developed from Systemic Functional Linguistics (SFL). SFL is a theory concerned with the processes of meaning making through language use 
within a social context(s). The theory also postulates that there are three kinds of meaning that are generated through these kinds of meaning making processes, categorically referred to as the metafunctions of language and are, the Ideational, Interpersonal and Textual functions of language. Couched with SFL, the appraisal framework is concerned with how writers/speakers approve and disapprove, enthuse and abhor, applaud and criticize, concerned with the construction by texts of communities of shared feelings and values, and with the linguistic mechanisms for the sharing of emotions, tastes and normative assessments. It is concerned with how writers/speakers construe for themselves particular authorial identities or personae, with how they align or disalign themselves with actual or potential respondents, and with how they construct for their texts an intended or ideal audience (Martin and White, 2005:1). Appraisal, and its configurations 'reporter voice' and Orbital Structure, inform the analysis of newspaper texts in the current study. White (2002) defines Appraisal as,

...concerned with the linguistic resources by which texts/speakers come to express, negotiate and naturalise particular inter-subjective and ultimately ideological positions. Within this broad scope, the theory is concerned more particularly with the language of evaluation, attitude and emotion, and with a set of resources which explicitly position a text's proposals and propositions interpersonally. That is, it is concerned with those meanings which vary the terms of the speaker's engagement with their utterances, which vary what is at stake interpersonally both in individual utterances and as the texts unfolds cumulatively.

From the definition provided by White (2000) we discern that the theory is concerned with the resources with which we can understand the manner in which speakers/writers construe for themselves particular authorial identities through the way(s) in which they align with or dissociate themselves from actual or potential respondents and or audiences (Martin and Rose, 2003). The framework is thus concerned with the analysis of the manner(s) in which the subjective presence of the author is visible through the manner in which they 'adopt' a position with regards to the material they are presenting (speaking/writing about) as well as those with whom they are communicating. Bednarek (2006) for example, argues that the appraisal analysis provides revelations for and of the context as well as 'the interpersonal character of evaluation as well as the communicative importance of evaluation itself'. Martin and White (2005) shed more light on this when they argue that Appraisal is a major discourse semantic resource construing interpersonal meanings.

\section{Analysing News Reports on the Extension of 'Sanctions' against Zimbabwe}

As highlighted earlier on. politically, the country is characterized by a GNU between Zimbabwe's three major political parties - ZANU PF, led by the incumbent president Robert Gabriel Mugabe and the two formation of the MDC - that is, MDC-T (the formation led by Morgan Tsvangirai, regarded as the biggest political challenge to Mugabe since the attainment of independence in 1980) and MDC-N (the breakaway formation once led by Professor Arthur Mutambara and now led by Professor Welshman Ncube). This political situation has highly polarized the media and subsequently, media stances which evince inclinations towards either of the two major parties to the unity government, ZANU PF and 
MDC. The state owned newspapers are regarded as political mouthpieces of ZANU PF while the private owned newspapers largely assumed and anti-ZANU PF stance. News reports are thus analysed in this context of polarity.

Despite ZANU PF launching of the Anti-Sanctions and Petition Campaign lobbying for the lifting of the embargo by both the USA and the EU, the 'sanctions' were renewed on several occasions. During the period under study, the USA and EU extended the 'sanctions' twice, in March 2011 and in March 2012. Both extensions were for a further period of one year. At the time of writing, the 'sanctions' against Zimbabwe are still in effect. This section analyses news reports on the extension of the 'sanctions'. In analysing the proliferation of attitudinal evaluative meanings, the study makes use of the analytical key proposed by Van and Thomson (2008: 55) which is reproduced below:

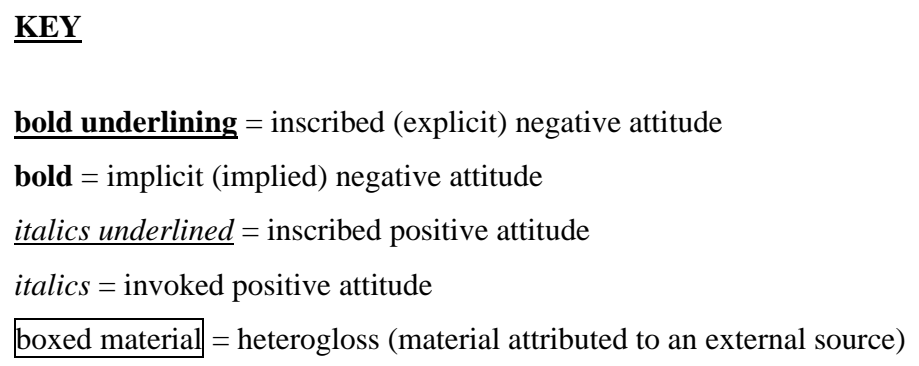

$\underline{\text { KEY }}$

bold underlining $=$ inscribed (explicit) negative attitude

bold = implicit (implied) negative attitude

$\underline{\text { italics } \text { underlined }}=$ inscribed positive attitude

italics $=$ invoked positive attitude

boxed material $=$ heterogloss (material attributed to an external source)

The subtype of the attitude is indicated in square brackets immediately following the relevant span of text:

$[\mathrm{j}]=$ judgement (positive/negative assessment of human behaviour in terms of social norms)

[ap] = appreciation (positive/negative assessment of objects, artefacts, events and states of affairs in terms of systems of aesthetics and other systems of social valuation)

$[\mathrm{af}]=$ affect (positive/negative emotional response); $1^{\text {st }}$ af $=$ first person or authorial affect; $3^{\text {rd }}$ af $=$ observed affect, i.e. the reporter describing the emotional responses of third parties.

\section{Kinds of attribution}

$<$ ack $>=$ 'acknowledgement': material is attributed to some external source by means of quotation and related formulations. Nothing in the lexicogrammar of the words by which the quotation is framed indicates where the writer stands with respect to propositions being presented - i.e. there is no overt indication of the writer favouring or disfavouring the attributed material. It is however possible that the writer's position vis-à-vis the attributed material will be indicated elsewhere in the text. Attribution is typically via a formulation involving reporting verbs - for example, "X stated that...", "X argues that...", "X believes that..." or through adjuncts such as "according to X..."

$<$ end $>=$ 'endorsement': material is attributed to an external source - as is the case with acknowledgement - but the framing is such as to indicate that the writer holds the material as true or valid - for example by means of 'factive' reporting such as 'to prove', 'to show' or 'to demonstrate';

$<$ dist $>=$ 'distancing': material is attributed to an external source - as in the case of acknowledgement - but the framing is such as to indicate that the writer holds the material to be still open to question, as not yet proved. Distancing in English is typically achieved by the use of the reporting verb 'to claim' and by the use of so called 'scare quotes'.

*** There is a notion of 'proclamation' <proc> which Van and Thomson (2008) describe as those instances when the reporter makes overt interventions into the text which "present themselves as challenging or dismissing some alternative viewpoints." 
4.1 The Herald (04 May, 2011)

\begin{tabular}{|c|c|c|}
\hline & APPRAISAL ANALYSIS & $\begin{array}{l}\text { ORBITAL STRUCTURE } \\
\text { ANALYSIS }\end{array}$ \\
\hline 001 & $\begin{array}{l}\text { EU not ready [j] to lift sanctions } \\
\text { Herald Reporter }\end{array}$ & $\begin{array}{l}\text { Nucleus: Headline } \\
\text { (The EU is not yet ready to } \\
\text { make a commitment to lifting } \\
\text { the sanctions against } \\
\text { Zimbabwe) }\end{array}$ \\
\hline 005 & $\begin{array}{l}\text { THE EU has welcomed the progress [ap] in the } \\
\text { on-going talks [ap] between the three parties in the } \\
\text { inclusive Government, but still insists [j] the bloc is } \\
\text { not committed [j] to immediately lift illegal } \\
\text { sanctions [j/ap] imposed on Zimbabwe. }\end{array}$ & $\begin{array}{l}\text { Nucleus: Lead (Appraisal/ } \\
\text { Elaboration) } \\
\text { (Authorial inscribed } \\
\text { evaluations of state of affairs } \\
\text { in Zimbabwe. Restatement } \\
\text { and evaluation of EU stance } \\
\text { as expressed in headline) }\end{array}$ \\
\hline 010 & 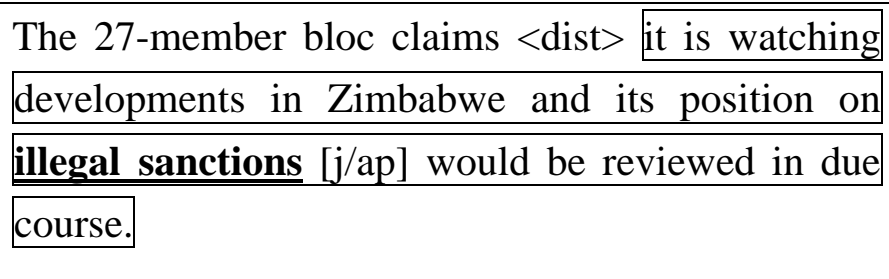 & $\begin{array}{l}\text { Satellite 1: Elaboration } \\
\text { (Restates the headline } \\
\text { proposition and specifies the } \\
\text { EU position with regards to } \\
\text { lifting sanctions) }\end{array}$ \\
\hline 015 & $\begin{array}{l}\text { EU representative to Zimbabwe, } \mathrm{Mr} \text { Ado } \\
\text { Dell'Aricia, said this yesterday while addressing } \\
\text { journalists ahead of the celebrations to mark the EU } \\
\text { Day on May } 9 .\end{array}$ & $\begin{array}{l}\text { Satellite 2: } \\
\text { Contextualisation } \\
\text { (Social context in which the } \\
\text { EU position is expressed) }\end{array}$ \\
\hline 020 & 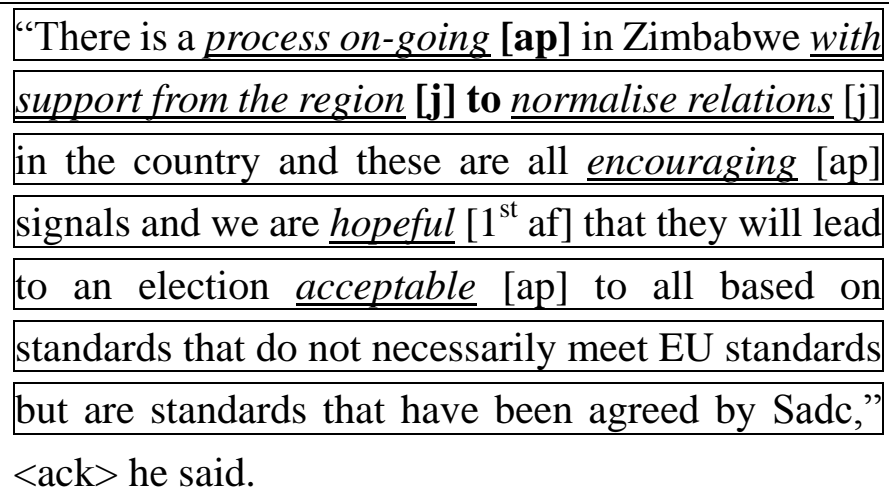 & $\begin{array}{l}\text { Satellite 3: Justification/ } \\
\text { Appraisal } \\
\text { (Specifies reasons for EU } \\
\text { position on lifting sanctions } \\
\text { and evaluates the state of } \\
\text { affairs in Zimbabwe related to } \\
\text { the lifting of sanctions) }\end{array}$ \\
\hline 025 & $\begin{array}{l}\text { Mr Dell'Aricia said <ack }>\text { the removal [j] of } \\
\text { persons on the illegal sanctions [j/ap] list was an } \\
\text { on-going exercise and would be determined by } \\
\text { developments in the country. }\end{array}$ & $\begin{array}{l}\text { Satellite 4: Justification } \\
\text { (Further specification of } \\
\text { reasons for EU position on } \\
\text { lifting sanctions) }\end{array}$ \\
\hline & "It is a continuing process and already several & Satellite 5: Justification \\
\hline
\end{tabular}




\begin{tabular}{|c|c|c|}
\hline 030 & $\begin{array}{l}\text { people were taken away from the list, the EU is } \\
\text { ready to review the process based on the reports we } \\
\text { receive from Zimbabweans [ap],"] <ack>Mr } \\
\text { Dell'Aricia said. }\end{array}$ & $\begin{array}{l}\text { (Further specification of } \\
\text { reasons for EU position on } \\
\text { lifting sanctions) }\end{array}$ \\
\hline 035 & $\begin{array}{l}\text { The EU removed } 35 \text { people from the travel embargo } \\
\text { in February this year and this followed revelations } \\
\text { [ap] by whistleblower [j] website that MDC-T } \\
\text { secretary general Mr Tendai Biti was instrumental } \\
\text { [j] in determining the individuals that were denied } \\
\text { entry into the bloc. }\end{array}$ & $\begin{array}{l}\text { Satellite } \\
\text { Contextualisation } \\
\text { (Specifies prior situation/ } \\
\text { context in which EU position } \\
\text { is made) }\end{array}$ \\
\hline 040 & $\begin{array}{l}\text { Mr Dell'Aricia said }<\text { ack }>\text { the EU hoped }\left[3^{\text {rd }} \text { af }\right] \text { the } \\
\text { three parties would make further progress in talks } \\
\text { that were scheduled to be held in South Africa } \\
\text { between the negotiators and the facilitation team } \\
\text { representing Sadc-appointed mediator and South } \\
\text { African president Mr Jacob Zuma. }\end{array}$ & $\begin{array}{l}\text { Satellite 7: Elaboration } \\
\text { (Specification of the EU } \\
\text { position regards sanctions) }\end{array}$ \\
\hline 045 & $\begin{array}{l}\text { The EU envoy denied }[j] \text { that they had stalled } \\
\text { negotiating [j] with the Zimbabwe Government in } \\
\text { favour of the Sadc effort. }\end{array}$ & $\begin{array}{l}\text { Satellite 8: Elaboration } \\
\text { (Further specification of the } \\
\text { EU position regards } \\
\text { sanctions) }\end{array}$ \\
\hline 050 & $\begin{array}{l}\text { "The Sadc senior officials visit to the EU is based on } \\
\text { a resolution of August last year at the Sadc Summit } \\
\text { held in Namibia. They presented their position and } \\
\text { the EU presented theirs," < <ack> he said. }\end{array}$ & $\begin{array}{l}\text { Satellite 9: Elaboration } \\
\text { (Further specification of the } \\
\text { EU position regards } \\
\text { sanctions) }\end{array}$ \\
\hline 055 & $\begin{array}{l}\text { Mr Dell'Aricia said }<\text { ack }>\text { dialogue between the EU } \\
\text { and Zimbabwe had been transferred to Harare and } \\
\text { they were now waiting for signals from Zimbabwe's } \\
\text { Foreign Affairs Ministry on the next dates for their } \\
\text { meeting. }\end{array}$ & $\begin{array}{l}\text { Satellite 10: Elaboration } \\
\text { (Further specification of the } \\
\text { EU position regards } \\
\text { sanctions) }\end{array}$ \\
\hline 060 & $\begin{array}{l}\text { "There is political dialogue and it was transferred to } \\
\text { Harare. We have held one meeting since the } \\
\text { beginning of the year and we are likely to hold } \\
\text { another one depending on the Ministry of Foreign } \\
\text { Affairs," <ack> he said. }\end{array}$ & $\begin{array}{l}\text { Satellite 11: Elaboration } \\
\text { (Further specification of the } \\
\text { EU position regards } \\
\text { sanctions) }\end{array}$ \\
\hline
\end{tabular}




\begin{tabular}{|l|l|l|}
\hline 065 & $\begin{array}{l}\text { Efforts to get a comment from the Minister of } \\
\text { Foreign Affairs Simbarashe Mumbengegwi and the } \\
\text { permanent secretary Mr Joey Bimha were fruitless } \\
\text { yesterday. }\end{array}$ & $\begin{array}{l}\text { Satellite } \\
\text { Intertextualisation } \\
\text { (Extratextual information on } \\
\text { Zimbabwe's government } \\
\text { position regards the } \\
\text { sanctions) }\end{array}$ \\
\hline 070 & $\begin{array}{l}\text { The dialogue between the two parties stalled [ap] } \\
\text { after some members of the Zimbabwean team } \\
\text { including Justice and Legal Affairs Minister } \\
\text { Chinamasa were denied [j] visas to enter the EU. }\end{array}$ & $\begin{array}{l}\text { Satellite } \\
\text { Contextualisation } \\
\text { (Prior political context before } \\
\text { the EU current position) }\end{array}$ \\
\hline 075 & $\begin{array}{l}\text { Minister Chinamasa who is a member of the team } \\
\text { was denied [j] a visa on two occasions and was at } \\
\text { one time detained [j] at Frankfurt Airport in } \\
\text { Germany on his way to attend the talks in Brussels, } \\
\text { Belgium. }\end{array}$ & $\begin{array}{l}\text { Satellite } \\
\text { Contextualisation } \\
\text { Further specification of prior } \\
\text { political context before the } \\
\text { EU current position) }\end{array}$ \\
\hline $\begin{array}{l}\text { The team also includes Minister Mumbengegwi, } \\
\text { Regional Integration and International Co-operation } \\
\text { Minister, Priscilla Misihairabwi-Mushonga and } \\
\text { Energy and Power Development Minister Elton } \\
\text { Mangoma and senior Government officials. }\end{array}$ & $\begin{array}{l}\text { Satellite } \\
\text { Contextualisation } \\
\text { (Further specification of prior } \\
\text { political context before the } \\
\text { EU current position) }\end{array}$ \\
\hline
\end{tabular}

\subsubsection{Appraisal and Orbital/Satellite Structure Analysis}

The propositions made by the news report assume an authorial position that portrays a positive image of the country by making proclamations that despite the EU not lifting sanctions against the country, progress can be noticed in the negotiations between Zimbabwe and the EU towards achieving that. The report also presents authorial positive evaluations of the 'on-going talks' between Zimbabwe and the EU aimed at the possibility for the lifting of the sanctions. The news report chooses not to portray a gloomy picture on the extension of sanctions by the EU but focuses instead of the positive developments on the EU - Zimbabwe relations with regards to the negotiations aimed at a possible lifting of the sanctions. The voice of the EU representative to Zimbabwe is called upon to support this authorial position. Through the authorial voice, this positive evaluation is espoused through inscribed positive APPRECIATION which express the situation and status of both the country and negotiations as 'hopeful' (019, 039), 'encouraging' (019) and showing 'progress' (003) - a position that is also cemented through attributed inscribed positive evaluations, specifically through the voice of EU representative to Zimbabwe, Mr Ado Dell'Aricia who is quoted as having stated that $(016-023)$, 
"There is a process on-going [ap] in Zimbabwe with support from the region [j] to normalise relations [j] in the country and these are all encouraging [ap] signals and we are hopeful $\left[1^{\mathrm{st}}\right.$ af] that they will lead to an election acceptable [ap] to all based on standards that do not necessarily meet EU standards but are standards that have been agreed by Sadc," <ack> he said.

This stance is further expressed through tokenised invocations, espoused from both the authorial voice as well as attributed material. The authorial voice in this report thus assumes the positive evaluative position that the EU acknowledges the progress that the negotiations have yielded. Instances of inscribed authorial negative evaluations through both APPRECIATION and JUDGEMENT resources are made of the sanctions as well as MDC-T, and in particular its Secretary General, Tendai Biti. Inscribed negative evaluations of the sanctions are evinced by a consistent tagging of the sanctions as 'illegal sanctions' (006 007, 010, 025). This is a position that is established through authorial inscriptions in the lead and is followed through in several other paragraphs within the body of the news report through both the authorial voice as well as attributions. This position notably reverberates with the official position of ZANU PF regards the sanctions, a position that critiques and challenges their legitimacy. It is also a position that is consistent with the position assumed by the publication in almost all of its news reports on the sanctions as earlier analyses will show.

Some instances of negative evaluations of the MDC-T leadership, specifically MDC-T Secretary General, Tendai Biti as being responsible for the sanctions and also having an influence on the position that the EU assumes with regards to the sanctions on Zimbabwe, also occur in the news report. For example, in this news report, Biti is described as having the power to influence who gets to be removed from the sanctions list and who doesn't, a revelation attributed to an external source - 'the whistleblower website' (035). In keeping with the observations made earlier on in the chapter regards co-texts, these evaluations made of Tendai Biti speak to earlier texts from both The Herald as well as ZANU PF website that accuse the MDC-T as responsible for calling for the imposition of the sanctions. The notion of subjective selection of an 'angle' to a story acquires relevance here too, especially so in light of how the news report selects what is considered to be newsworthy as well as who is regarded as a worthy 'voice' - external voice used for evaluation purposes. For example, rather than the report focusing on the fact that the EU has extended the sanctions on Zimbabwe, the report elects to focus on a positive evaluation of the dialogue between Zimbabwe and the EU which represents a possibility for the lifting of the sanctions. This kind of bias occurs because news reporting discourse is heavily ideologically laden (Höglund, 2008).

4.2 NewsDay (17 May, 2012)

\begin{tabular}{|l|l|l|}
\hline & APPRAISAL ANALYSIS & $\begin{array}{l}\text { ORBITAL STRUCTURE } \\
\text { ANALYSIS }\end{array}$ \\
\hline 001 & Sanctions will stay [ap] - US & Nucleus: Headline \\
\hline
\end{tabular}




\begin{tabular}{|c|c|c|}
\hline & Moses Matenga: Staff Reporter & $\begin{array}{l}\text { (Attributed headline: } \\
\text { Sanctions against Zimbabwe } \\
\text { will stay in place) }\end{array}$ \\
\hline 005 & $\begin{array}{l}\text { The United States will not remove sanctions against } \\
\text { President Robert Mugabe and some of the Zanu PF } \\
\text { officials until reforms towards democratisation } \\
\text { are met }[\mathrm{j} / \mathrm{ap}], \text { < <ack> an official said yesterday. }\end{array}$ & $\begin{array}{l}\text { Nucleus: Lead } \\
\text { (Elaboration/ Justification/ } \\
\text { Appraisal) } \\
\text { (Restates the statement of } \\
\text { headline, specifies reason } \\
\text { why sanctions will stay in } \\
\text { place and evaluation of the } \\
\text { state of affairs/political } \\
\text { situation in Zimbabwe) }\end{array}$ \\
\hline 010 & $\begin{array}{l}\text { Speaking to journalists from different African } \\
\text { countries during a teleconference yesterday, } \\
\text { Assistant Secretary of State for African Affairs } \\
\text { Johnnie Carson maintained that <ack> the sanctions } \\
\text { were only targeted [ap] and not hurting [ } 3^{\text {rd }} \text { af] } \\
\text { ordinary Zimbabweans but the few people in Zanu } \\
\text { PF and government. }\end{array}$ & $\begin{array}{l}\text { Satellite 1: } \\
\text { Contextualisation/ } \\
\text { Appraisal } \\
\text { (Specifies social context in } \\
\text { which US position on not } \\
\text { lifting sanction is expressed. } \\
\text { Attributed evaluation of the } \\
\text { sanctions and their 'effects') }\end{array}$ \\
\hline 015 & $\begin{array}{l}\text { "The US will continue to maintain sanctions on } \\
\text { Zimbabwe and will do so until we believe [ } 1^{\text {st }} \text { af] } \\
\text { substantial irreversible progress [ap] has been made } \\
\text { on implementing the peace agreement, } \\
\text { Carson said. }\end{array}$ & $\begin{array}{l}\text { Satellite 2: Elaboration/ } \\
\text { Justification } \\
\text { (Restates the US position and } \\
\text { specifies reason why } \\
\text { sanctions will stay) }\end{array}$ \\
\hline 020 & $\begin{array}{l}\text { The sanctions are against individuals, } 60 \\
\text { government officials and equally 50-60 } \\
\text { Zimbabwean companies and corporations under the } \\
\text { control of Zanu PF or the military. }\end{array}$ & $\begin{array}{l}\text { Satellite 3: Appraisal } \\
\text { (Authorial evaluation of the } \\
\text { nature of sanctions) }\end{array}$ \\
\hline 025 & $\begin{array}{l}\text { "They are not sanctions specific to Zimbabwe as a } \\
\text { country or designed to hurt the people of Zimbabwe } \\
\text { who have been punished [j] enough by the } \\
\text { treatment by the government," <ack> he said. }\end{array}$ & $\begin{array}{l}\text { Satellite 4: Appraisal } \\
\text { (Attributed evaluation of the } \\
\text { nature of the sanctions) }\end{array}$ \\
\hline 030 & $\begin{array}{l}\text { Carson said <ack> the sanctions were focused on } \\
\text { individuals [ap] and that his country would continue } \\
\text { reviewing them and taking a few people off. }\end{array}$ & $\begin{array}{l}\text { Satellite 5: Appraisal } \\
\text { (Further attributed evaluation } \\
\text { of the nature of the sanctions) }\end{array}$ \\
\hline
\end{tabular}




\begin{tabular}{|c|c|c|}
\hline & "They will remain in place as long as we don't see & \multirow{3}{*}{$\begin{array}{l}\text { Satellite 6: Justification } \\
\text { (Specifies reasons why } \\
\text { sanctions will stay in place) }\end{array}$} \\
\hline & sufficient progress $[\mathrm{j}]$ in the area of & \\
\hline & democratisation," <ack> he said. & \\
\hline 035 & $\begin{array}{l}\text { The United States and the European Union imposed } \\
\text { targeted sanctions [j/ap] on government officials } \\
\text { and members of Zanu PF in } 2002 \text { after a series of } \\
\text { <dist> alleged human rights abuses against } \\
\text { perceived opposition supporters [j]. }\end{array}$ & $\begin{array}{l}\text { Satellite 7: Appraisal/ } \\
\text { Elaboration } \\
\text { (Authorial evaluation of the } \\
\text { sanctions and specification of } \\
\text { reasons why sanctions were } \\
\text { imposed) }\end{array}$ \\
\hline 040 & $\begin{array}{l}\text { Recently Zimbabwe sent a delegation to the } \\
\text { European Union (EU) to negotiate the removal of } \\
\text { sanctions. }\end{array}$ & $\begin{array}{l}\text { Satellite } \\
\text { Contextualisation } \\
\text { (Specifies prior political } \\
\text { context in which sanctions are } \\
\text { imposed and stay in effect) }\end{array}$ \\
\hline
\end{tabular}

\subsubsection{Appraisal and Orbital/Satellite Structure Analysis}

The news report, which is very brief, makes the propositions that negatively evaluate the human rights and reforms towards democratisation situations in Zimbabwe. The news report espouses the concern that there is still not much done in Zimbabwe with regards to improving the human rights situation and implementing democratic reforms. This being the case, the US and EU are therefore not ready to lift sanctions until there is visible movement towards addressing this. No obvious authorial stances are assumed in the story save for only one instance which we can classify as tokenised authorial evaluation. This occurs in the body of the news report and its intent is to give some 'positive' evaluation of the sanctions. The stance assumed by the author in this regard is that the sanctions are not on the country but are targeted on named individuals $(019-022)$.

The sanctions are against individuals, 60 government officials and equally 50-60 Zimbabwean companies and corporations under the control of Zanu PF or the military.

This token, which downplays the claim by ZANU PF (as expressed in section $\mathbf{5 . 5}$ ), that the sanctions were on the country and affecting service delivery and progress at national level, is evaluative even though there are no explicit appraisal resources that we can mark in it. The position assumed by the authorised voice through the tokenised invocation above serves as reinforcement for one of the major propositions of the news report, a proposition that believes that the sanctions were not imposed on the country as a whole but only on a few selected individuals. This position is well established through inscribed attributed positive APPRECIATION/JUDGEMENT evaluations of the sanctions as well as the negative JUDGEMENT evaluations of ZANU PF as part of government. In light of this we observe the following extracts $(007-018)$; 
Speaking to journalists from different African countries during a teleconference yesterday, Assistant Secretary of State for African Affairs Johnnie Carson maintained that $\left\langle\right.$ ack $>$ the sanctions were only targeted $[\mathrm{ap}]$ and not hurting $\left[3^{\text {rd }}\right.$ af] ordinary Zimbabweans but the few people in Zanu PF and government.

as well as $(027-030)$,

Carson said <ack> the sanctions were focused on individuals [ap] and that his country would continue reviewing them and taking a few people off.

as well as $(023-026)$,

"They are not sanctions specific to Zimbabwe as a country or designed to hurt the people [ap] of Zimbabwe who have been punished [j] enough by the treatment by the government," <ack> he said.

Through these attributed materials, largely attributed to US Assistant Secretary of State for African Affairs, Johnnie Carson, we observe evidence of negative evaluations of the government, in this case ZANU PF as having 'punished' (025) the people enough and for 'gross human rights abuses against perceived opposition supporters' (037 - 038). We also note the positive evaluations of the sanctions, which are said to be 'targeted' $(011,035)$, 'not hurting ordinary Zimbabweans' $(011-013)$ and 'focused on individuals' (027 028). While we cannot attribute the evaluations made through attributed materials to authorial position, the tokenised invocations that reinforce the evaluations made through such materials are interesting it terms of Jullian's (2011) observations of authorial appraisals made through the voices of sources discussed at several instances in the previous analyses of news reports.

Another major proposition of the news report, which I will not discuss in detail here, is with regards to the position assumed by the USA for maintaining sanctions on Zimbabwe. Through inscribed attributed evaluations, the news report also negatively evaluates the state of affairs in the country. It is the concern of the report that there still is no real reform towards democratisation in the country and that the USA will only lift sanctions if these reforms are implemented. In a manner of speaking, through these evaluations, we discern attitudinal evaluations of both APPRECIATION (which is made on the state of affairs) as well as of JUDGEMENT (on the part of ZANU PF for refraining from implementing the reforms).

It is evident from the above analyses and discussions that structurally, as with many news reports in Zimbabwean newspapers the news report avoids the proliferation of the authorial voice through a heavy reliance on the voices of others. For example, in this particular report, it is evident that, save for the single instance of authorial evaluation through a token, all attitudinal resources are attributed to external sources. The positions that are established by the headline and the lead and which are elaborated on and contextualised within the body of the news report are both framed in attribution. The same observation applies to all the inscribed evaluations, which again are occurring as attributed material. This presents a challenge for determining the real source of the evaluations as from one angle it could signal authorial tact to 'remove' the authorial voice from attitudinal evaluations. On the other hand 
it could be analysed in terms of selective and purposeful sourcing of external voices, a method through which the authorial voice makes attitudinal evaluations 'through the words of others' as expressed by Jullian (2011) and Gales (2010).

\section{Comparing Authorial Stance-Taking in the Two 'Hard' News Reports}

Two notions related to the analysis of authorial subjectivities analysed through the 'reporter voice' configuration by focusing on evaluative resources are 'stancetaking' (du Bois, 2007 and Gales, 2010) and 'appraising through someone else's words' (Jullian, 2011).The Zimbabwean press is polarised along political lines. Such polarities manifest themselves in the manner in which evaluative language is used through both the authorial voice/stance as well as through materials attributed to external sources. The selections of newsworthy issues in event news reports as well as the source(s) of external voices are also affected by the politically influenced choices within this media divide. The structural arrangement of matter in news reports in most Zimbabwean newspapers follows a trend in which the news reports unfold through evaluations made by external sources. It seems there is a perception that in order for one to maintain a semblance of 'neutrality'/'objectivity', one needs to distance themselves as far as possible from the explicit expression of opinion. Such a feat is achieved it seems, by a high proliferation of not only acknowledged but quoted materials in the news reports.

The two news reports on the extension of the embargo exhibit authorial subjectivities which cut along political ideology. There is evidence of positive JUDGEMENT evaluations of ZANU $\mathrm{PF}$ in The Herald news report. The political party is positively evaluated for its fight against the sanctions and the role it plays in defending the interests of the nation at large. Whereas the extension of the embargo infers negativity, The Herald news report elects to focus on the 'positive' side of the debacle by focusing on the 'positive developments in the ongoing negotiations to lift the sanctions'. There are also, following such a pattern, negative JUDGEMENT evaluations of the MDC-T as being responsible for the imposition and the subsequent extensions of the sanctions. Such negative evaluations exhibit themselves through authorial inscriptions, which in the process, continue perpetuating the position expressed by ZANU PF with regards to the real cause of the imposition of the sanctions. The position established thus, is that the sanctions are an act of British vengeance for the land redistribution exercise undertaken by the ZANU PF leadership and governance.

In light of the foregoing discussion, we also can discern Anti-ZANU PF sentiments expressed within the private-owned newspaper, NewsDay. There are no visible authorial inscriptions within the NewsDay report and all evaluations are expressed through both attributed inscriptions and tokens. On the other hand, while the bulk of the evaluations are largely framed in attribution, we observe instances of authorial evaluations as well, evaluations which largely evince a negative imaging of ZANU PF as having been responsible for the imposition of the sanctions because of its culture of violence characterised by gross human rights abuses and political intolerance. In short, the propositions expressed in the NewsDay echoes the positions expressed by the EU and the USA for the imposition of sanctions against Zimbabwe, a position clearly established in the introductory sections of this article. There 
seems to be a conspiracy within the newspaper to debunk all the claims made by ZANU PF with regards to the sanctions and thus in the process assume an anti-ZANU PF stance.

Juxtaposing the ideological differences between the news reports again resonates with the notion of stance taking - a powerful construct that is manifested in a multitude of ways as it allows speakers and writers not only to express their personal attitudes, feelings, and value judgements about a person or object and their commitment to a proposition (Biber et al., 1999; Conrad and Biber, 2000), but also to negotiate power and solidarity between themselves and others and between two or more 'others' (Martin and White, 2005) and to convey presupposed systems of sociocultural as well as socio-political values (du Bois, 2007: 139). According to Gales (2010) this iterative understanding of 'stance' and 'stancetaking' is essential for a variety of reasons. Largely, stance, in its broadest sense, 'is a cognitive device for interpreting the world' (Bednarek, 2006:4), which, when linguistically expressed, also allows us to offer this interpretation to others.

\section{Conclusion}

The Zimbabwe 'sanctions' are a highly politically contested issue in the country's current political dispensation - characterised by political blame games and contestations with regards to the way forward in dealing with the sanctions. The news reports exhibit a trend of being highly polarised along political ideological lines - a situation arising from the political differences that characterise the current political administration of the country. The article gave evidence that suggests that the general structure of the 'hard news' report in Zimbabwean newspapers in English exhibit a structural arrangement that largely protects the authorial voice by making evaluations through external voices. A very important notion in the appraisal analyses done for news stories in Zimbabwean newspapers, as has been consistently expressed in the article, in the notion of 'appraising through the words of others' (Jullian, 2011). This is so, because of the general structure of the hard news report in the Zimbabwean news reporting culture. This also explains why the larger part of evaluative resources, both inscriptions and invocations, are expressed through these external voices. The structural arrangement of the news reports in Zimbabwean newspapers would thus at best be described as a sequential arrangement of quoted material. Of significance to note is that there seems to be a trend cutting across the publications in which the headline and lead do not merely function as synopses for the major preoccupations of the news reports but are used to establish an authorial evaluative position from which news angles and what is considered to be newsworthy is selected. Even a cursory glance at such reports, however, will reveal a trend in which such attributed materials serve as reinforcements and/or elucidations of/to the positions established by the authorial voice in both the headlines and the leads of the news reports.

\section{References}

Bednarek, M. (2006). Evaluation in Media Discourse: Analysis of a Newspaper Corpus. London: Continuum. 


\section{Al Macrothink}

International Journal of Linguistics ISSN 1948-5425 2013, Vol. 5, No. 3

Du Bois, J. W. (2007). The stance triangle. In R. Englebretson (ed.) Stancetaking in discourse: Subjectivity, Evaluation, Interaction. Philadelphia, PA: John Benjamins, 139-182

Gales, T. A. (2010). 'Ideologies of Violence: A Corpus and Discourse Analytic Approach to Stance in Threatening Communications'. Unpublished PhD Thesis: University of California

Iedema, R., Feez, S., \& White, P.R.R. (1994). Media Literacy. Sydney: Disadvantaged Schools Program, NSW Department of School Education.

Jullian, P. M. (2011). Appraising through someone else's word: The evaluative power of quotations in news reports. Discourse and Society 22(6), $766-780$. http://dx.doi.org/10.1177/0957926511411697

Martin, J. R., \& White, P. R. R. (2005). The language of Evaluation: Appraisal in English. Palgrave Macmillan.

Martin, J. R., \& Rose, D. (2003). Working with discourse: Meaning beyond the clause. London: Continuum.

McCabe, A., \& Heilman, K. (2007). Textual and Interpersonal Differences between a News Report and an Editorial. Revista Alicantina de Estudios Ingleses (20), 139 - 56.

Sabao, C. (2013). The 'Reporter Voice' and 'Objectivity' in Cross-Linguistic Reporting of 'Controversial' News in Zimbabwean Newspapers. An Appraisal Approach. Unpublished PhD Thesis: Stellenbosch University, South Africa.

Thomson, E. A., White, P. R. R., \& Kitley, P. (2008). 'Objectivity' and 'hard news' reporting across cultures: Comparing the news report in English, French, Japanese and Indonesian $\begin{array}{llllllll}\text { journalism. } & \text { Journalism } & \text { Studies, } & 9 & (2), & 212 & - & 228 .\end{array}$ http://dx.doi.org/10.1080/14616700701848261

Van, T. T. H., \& Thomson, E. A. (2008). The nature of the 'Reporter Voice' in a Vietnamese Hard News Story. In E. A. Thomson and P. R. R. White (eds), Communicating Conflict: Multilingual Case Studies of the News Media. London: Continuum, 51 - 64.

White, P. R. R. (2000). Media objectivity and the rhetoric of news story structure. In E. Ventola (Ed), Discourse and Community: Doing Functional Linguistics. Language in Perfomance 21. Tubengen: Gunter Narr Varlag, 379 - 97.

White, P. R. R. (2002). Appraisal - the Language of Evaluation and Stance. In J. Verschueren, J.O.Östman, J. Blommaert and C. Bulcaen (eds), The Handbook of Pragmatics. Amsterdam/Philadelphia: John Benjamins, 1 - 23.

White, P. R. R., \& Thomson, E. A. (2008). The News Story as Rhetoric: Linguistic Approaches to the analysis of journalistic discourse. In E. A. Thomson and P. R. R. White (eds), Communicating Conflict: Multilingual Case Studies of the News Media. London: Continuum, $1-23$.

\section{Copyright Disclaimer}

Copyright reserved by the author(s). 


\section{Macrothink}

International Journal of Linguistics

ISSN 1948-5425

2013, Vol. 5, No. 3

This article is an open-access article distributed under the terms and conditions of the Creative Commons Attribution license (http://creativecommons.org/licenses/by/3.0/). 